\title{
Correlations Between the Autolytic Changes and Postmortem Interval in Refrigerated Cadavers
}

\author{
ELA ANDRA COCARIU ${ }^{1}$, V. MAGERIU ${ }^{2}$, FLORICA STĂNICEANU $^{2,3}$, \\ ALEXANDRA BASTIAN ${ }^{2,3}$, C. SOCOLIUC ${ }^{2,3}$, SABINA ZURAC ${ }^{2,3}$ \\ ${ }^{1}$ County Forensic Pathology Department Giurgiu, 5-7Alexandriei 5-7 Bvd, Giurgiu, Romania \\ ${ }^{2}$ Pathology Department of "Colentina" Clinical Hospital, 19-21 Ştefan cel Mare Bvd, Bucharest, Romania \\ ${ }^{3}$ UMF "Carol Davila”, School of Medicine, Eroii Sanitari Bvd, Bucharest, Romania
}

\begin{abstract}
Introduction. In forensic pathology the autolytic process has been observed and documented in order to determine the postmortem interval as accurately as possible. The observation and experiments have been carried out on cadavers exposed to environmental conditions - heat, humidity, air currents, soil, water.

Methods. For this study hematoxylin and eosin (HE) stained sections of organ samples from 30 autopsied bodies were examined under the microscope. Modifications of tissue and cell structures were noted in correlation with the bodies' time spent in the Morgue's mortuary refrigerator until the autopsy was performed, which varied between 24 hours and 22 days.

Results. All the organs sampled (lung, heart, liver and pancreas) showed severe autolytic alterations after 5 to 8 days. The most heavily affected was the pancreas, cells within Langherhans islets becoming complete autolyzed at the 36 hours mark. Inside organs, autolytic processes occur at different rates depending on the locations within that organ -deeply or superficial; in the heart after 4 or more days subendocardic myocardium shows less severe autolytic changes than the subepicardial one.

Conclusion. Autolytic processes have a delayed onset and a much lower progression rate in a cold controlled environment. Different organs suffer different rates of autolysis in correlation to their structure and enzymatic content.
\end{abstract}

Key words: autolysis, postmortem interval, autolytic alterations, cadavers, diagnostic errors, controlled environment.

\section{INTRODUCTION}

After death a corpse suffers the following early modifications: cooling, dehydration, hypostasis and rigidity onset, autolysis and respectively late destructive modifications (putrefaction) or conservative ones (mummification, saponification, lignification, adipocere formation, mineralization, or congelation [4]).

In literature these modifications were studied in order to determine as accurately as possible the postmortem interval. The majority of research has been conducted on subjects who's death and later discovery of the body was indoors or outdoors, being exposed to variations in temperature, humidity, air currents or when the death occurred in other location but they were stored in relatively controlled conditions - the forensic research facilities. Also, we found articles regarding autolytic modification in animal models, but only for few organs and all were carried out at different temperatures that did not allow for enzymes inactivation $[5,6]$. However, at least to our knowledge, no studies were per- formed in order to identify the impact of autolysis on refrigerated bodies and, especially, the potential of these alterations to interfere with histopathologic diagnosis of tissues harvested during autopsies.

Studying tissue autolysis in bodies subjected to long term cold environment storage allows the pathologist to take into account these modifications while examining a tissue section and to avoid any erroneous diagnostics beside the intra-vitam/ postmortem evaluation of a lesion (differential diagnostic between autolysis and ischemic necrosis) and the medical-legal implications of these.

\section{MATERIALS AND METHODS}

This is a retrospective study between 2010 and 2013, which included 30 cadavers from the Morgue of "Colentina" Clinical Hospital, Pathology Department where autopsies were carried out at 24 , $36,48,60,72$ hours and respectively at 3,5 (84h) 4 (96h), 5(120h), 7(168h), 8(192h), 11(264h), 16(384h) and 22(528h) days since the time of death (Table 1). 
Table 1

The number of cases studied for each postmortem interval

\begin{tabular}{|l|c|c|c|c|c|c|c|c|c|c|c|c|c|c|c|}
\hline $\begin{array}{l}\text { Postmortem } \\
\text { interval }\end{array}$ & $24 \mathrm{~h}$ & $36 \mathrm{~h}$ & $48 \mathrm{~h}$ & $60 \mathrm{~h}$ & $72 \mathrm{~h}$ & 3,5 & 4 days & 5 days & 8 days & 9 days & 10 days & 11 days & 12 days & 16 days & 22 days \\
\hline $\begin{array}{l}\text { Number of cases } \\
\text { (studied } \\
\text { autopsies) }\end{array}$ & 5 & 5 & 5 & 1 & 5 & 1 & 1 & 2 & 1 & 1 & 1 & 2 & 2 & 1 & 1 \\
\hline
\end{tabular}

According to the current legislation [7,8], immediately after death the cadavers were transferred in a clinic's special room where they were stored for two hours before being transferred to Hospital's Morgue; here they were stored at a constant temperature of $2^{\circ} \pm 1^{\circ} \mathrm{C}$ until the time of autopsy. During the autopsies all the organs were sampled whether they grossly appeared altered or not. In this study we included fragments of lung, heart, liver and pancreas; sampled fragments were left for 7 days in $10 \%$ formalin solution for fixation. They were processed using the Thermo SCIENTIFIC MICROM STP 420D tissue processor; the paraffin embedded tissues were sectioned with Leica RM2265 fully automated rotary microtome into 5 $\mu \mathrm{m}$ thin sections; sections were then mounted on a clear glass slide, then, deparaffinized, rehydrated and stained with hematoxylin and eosin stain (HE) using MICROM ROBOSTAINER HMS760 stainer; stained sections were dehydrated and slips mounted with PERTEX mounting medium on top of the clear glass slides. Organ sections were compared between each other and to sections from organ fragments obtained from living patients that have not subject of autolysis (biopsies, surgical obtained organ samples or organ excisions). Histopathological HE stained sections from Colentina's Hospital archive were examined, without resectioning any organs. We excluded from examination those organs that showed pathological alterations (infection, abscesses, benign or malignant pathology, infarction). The general architecture of each organ was noted as well as cellular membrane changes (loss of cellular limits), cytoplasmic staining and integrity, nucleolemma integrity, nuclear contraction or vacuolation, chromatin appearance.

\section{RESULTS}

We summarized the alterations occurred in different organs at various intervals after death.

\section{The Lung}

$-24 \mathrm{~h}$ : general architecture of pulmonary tissue is very well preserved - there are no differences with normal lung histology; alveolar and inflamematory cells are easily identifiable; respiratory epithelial within bronchi and bronchioles are focally detached from basement membrane and at the luminal pole cilia can be identified; lacunae within hyaline cartilage contain chondrocytes; all the pulmonary and blood cell structures (membrane, cytoplasm, nucleus) do not show any alterations.

$-36 \mathrm{~h}$ : generally the same aspect as the $24 \mathrm{~h}$ one; cilia of epithelial cells can be identified but they are beginning to disintegrate; in about $30 \%$ of the lacunae chondrocytes cannot be identified, the others have intensely vacuolated cytoplasm and pale basophilic pyknotic nucleus, with karyolysis or with diffuse chromatin granules and slight nucleo-lemma lysis (Figure 1).

$-48 \mathrm{~h}$ : slight fragmentation of interalveolar septa - the thinnest septa are affected.

$-60 \mathrm{~h}$ : alveoli are demarcated by rows of erythrocytes bordered by alveolar cells nuclei; lymphocytes show only fragments of cytoplasm; the nuclei of pleural mesothelium cannot be seen; in large and medium blood vessels both the endothelial cells and fibrocytes within the wall maintain their structure.

$-72 \mathrm{~h}$ : tissue architecture is beginning to fade focally - areas of lung parenchyma appear missing; thin interalveolar septa are fragmented in almost entire tissue mass; connective tissue and fibers that delimit the lobules keep their general appearance (high connective tissue content).

-3.5 days: same appearance as at $72 \mathrm{~h}$ (Figure 2).

-5-22 days: lung tissue is losing its architecture as the postmortem interval increases; the intraparenchymal optical empty spaces are multiplying; thick septa (containing large quantities of collagen) are more resistant to autolysis (Figure 3). For comparison we included two pictures of lung tissue, one with pulmonary oedema, the other one with pneumonia; in the first it is easily noticeable that in spite of 8 days (192h) of cold storage lung tissues show modification closer to those encountered after 36h; the latter shows almost complete autolysis of the tissue at the 5 days (120h) mark, the only structures remaining being the connective tissue texture of the organ (Figure 4). 


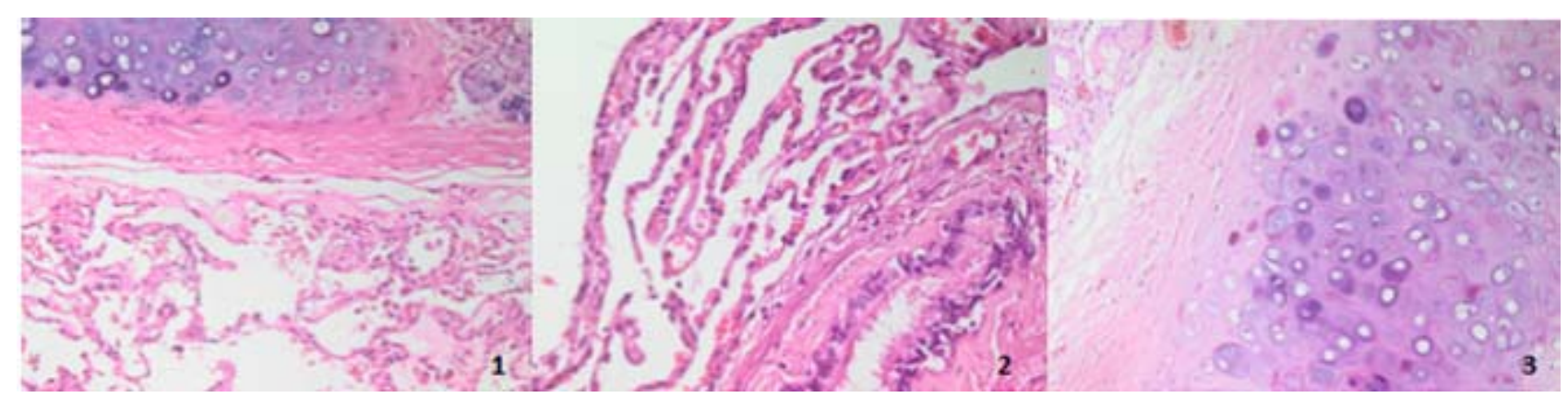

Figure 1. Lung HE, stain, 1-24h, 20X; 2-36h, 40X; 3-36h, 40X.

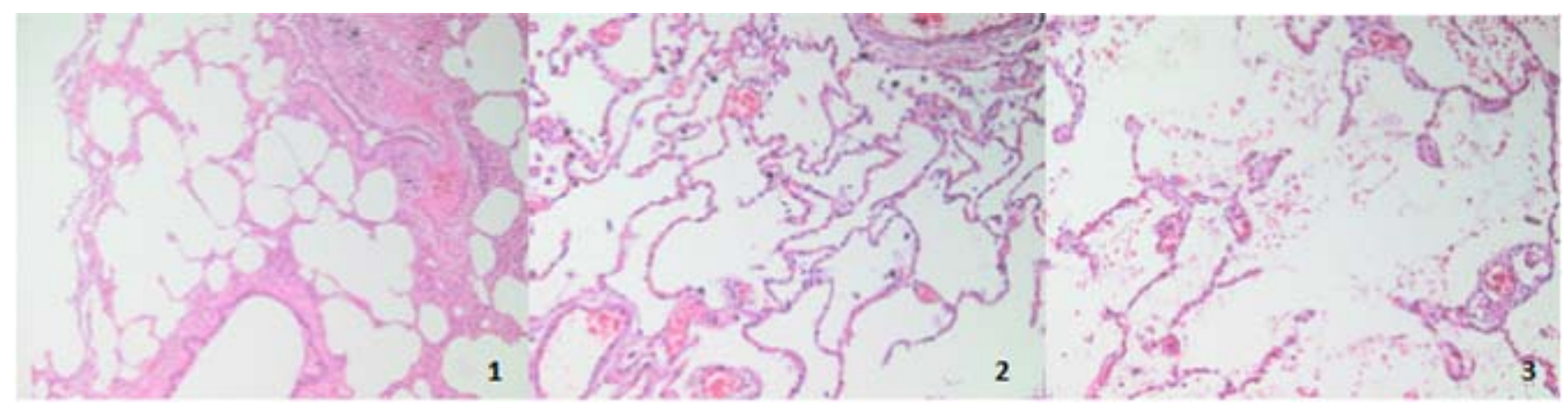

Figure 2. Lung, HE stain, 1-48h, 10X; 2-60h, 20X;3-72h, 20X.

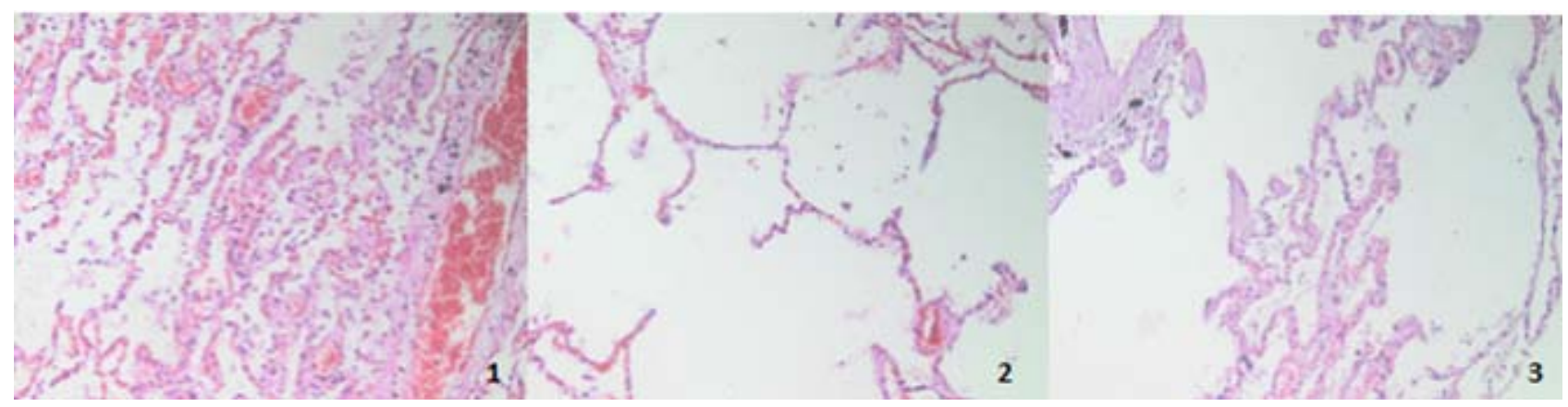

Figure 3. Lung, HE stain, 1-9 days, 20X; 2-16 days, 20X; 3-22 days, 20X.

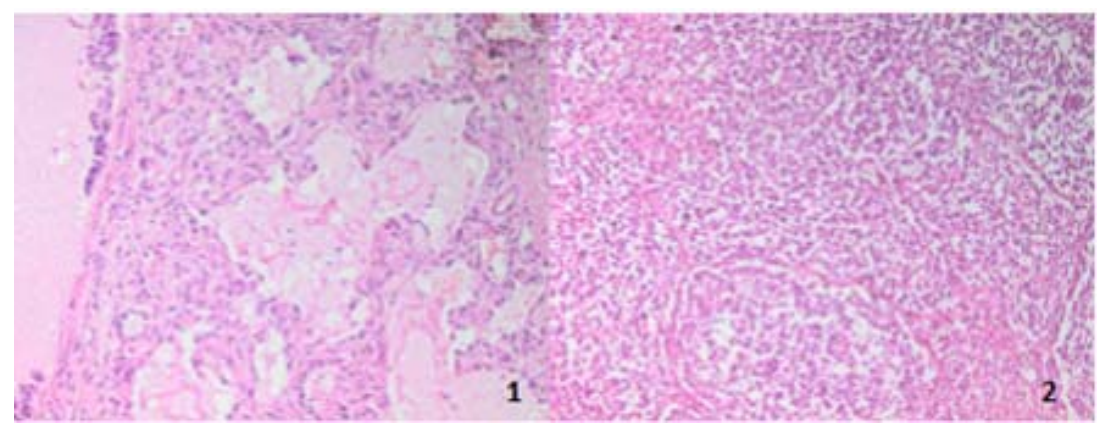

Figure 4. Lung HE stain, 1-8 days, edema and fibrosis; 2-5 days, pneumonia.

\section{The Heart}

$-24 \mathrm{~h}$ : tissue architecture is not modified; cardiac myocytes and their structures are easily identifiable; muscle striations are distinguishable; there are no autolytic modifications in the epicardium, endocardium and vascular endothelia.
- 36h: myocardial fibers are slightly spaced the appearance is very similar to minimal interstitial edema; the striations are still visible.

$-48 \mathrm{~h}$ : muscle fibers begin to separate (individualization); the majority of nuclei are ballooned with chromatin granules; occasionally the nuclei 
disappear and the places where the nuclei previously stood present a slight shadow; transversal striations are only visible in very few fibers (less than 5\%) but the longitudinal ones are beginning to become obvious (Figure 5).

$-60 \mathrm{~h}$ : the cellular membrane of the most myocardiocytes is completely autolyzed - cells are not well delimited any more, their exterior looking a little serrate; cytoplasm is made out of fine granules with small cleavage spaces; about $50 \%$ of cells do not show nuclei the rest showing either pyknotic nucleus with uneven borders or highly turgescent nucleus with uneven distribution of chromatin.

$-72 \mathrm{~h}$ : almost the entire mass of myocardial cells have lost or externalized their nuclei.

-3.5 days: in transverse section some fibers show slightly eccentric optical empty spaces (possibly the place previously occupied by the nucleus, Figure 6).

-4 days: fragmentation of the cytoplasm continues; in subepicardic adipose tissue nuclei are lysated in $50 \%$ of adipocytes.
-5 days: cytoplasm is more fragmented becoming increasingly granular but still well grouped the cells can be still identified.

-8 days: myocytes cannot be identified individually - cytoplasms are heavily fragmented with filamentary aspect.

-9 days: vascular endothelial cells cannot be identified.

$-10,11,12,16,22$ days: cytoplasmic debris have the same dimensions being separated by spaces relatively even spaced (Figure 7).

As a general observation: at myocardic level, the most affected area is the subepicardic one; when autopsy is performed more than 4 days postmortem, subendocardic myocardium shows also autolytic changes but the subendocardic alterations are not as severe as the subepicardic ones (there is an overall "delay" of 2 days between subendocardic and subepicardic autolysis).

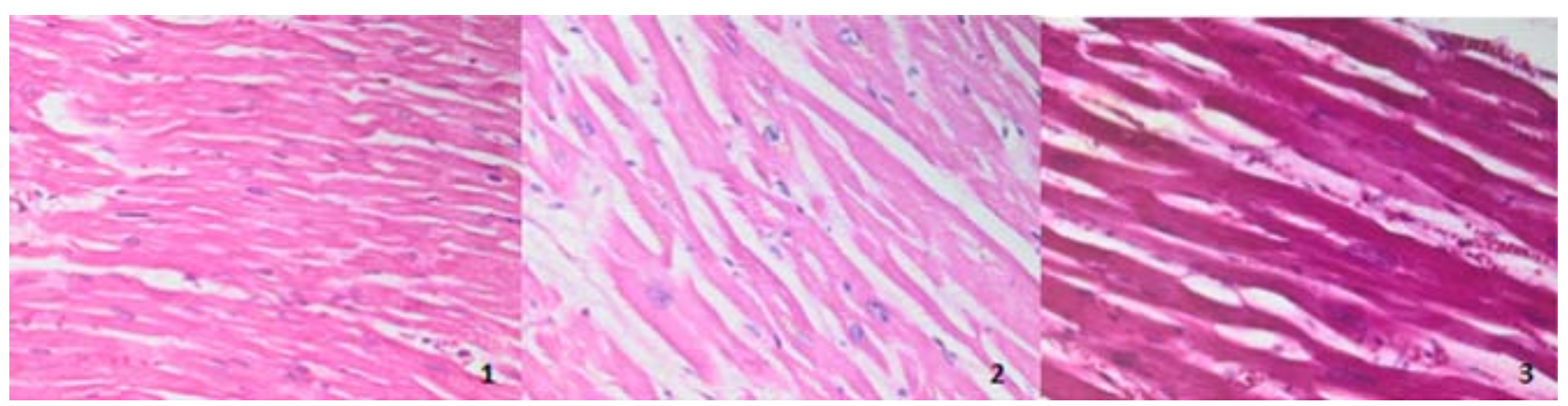

Figure 5. Heart, HE stain; 1-24h, 40X; 2-36h, 40X, 3-48h, 40X.

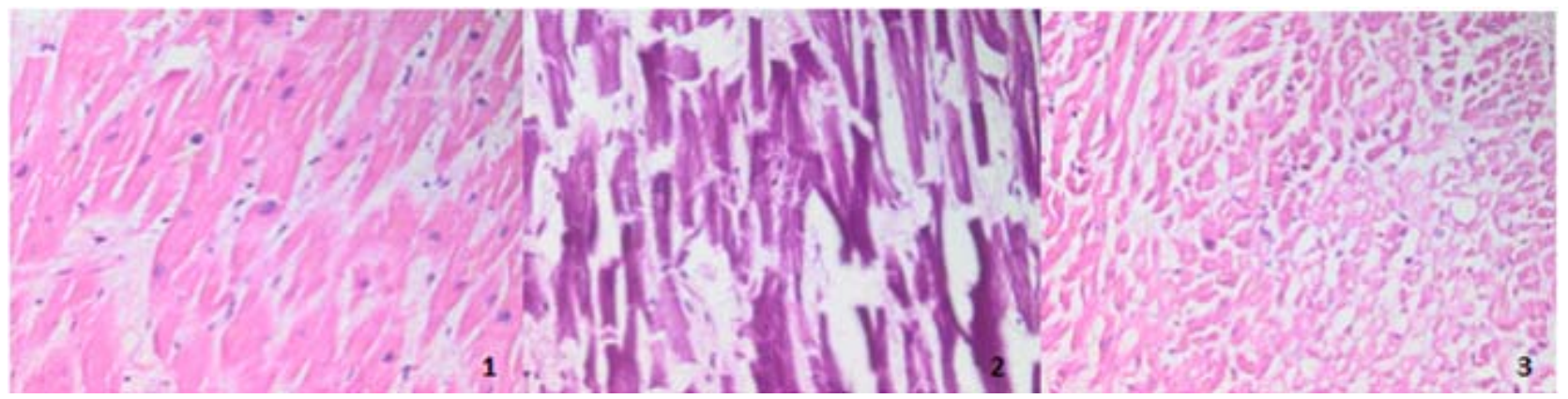

Figure 6. Heart, HE stain, 1-60h, 40X; 2-72h, 40X; 303.5 days, 40X.

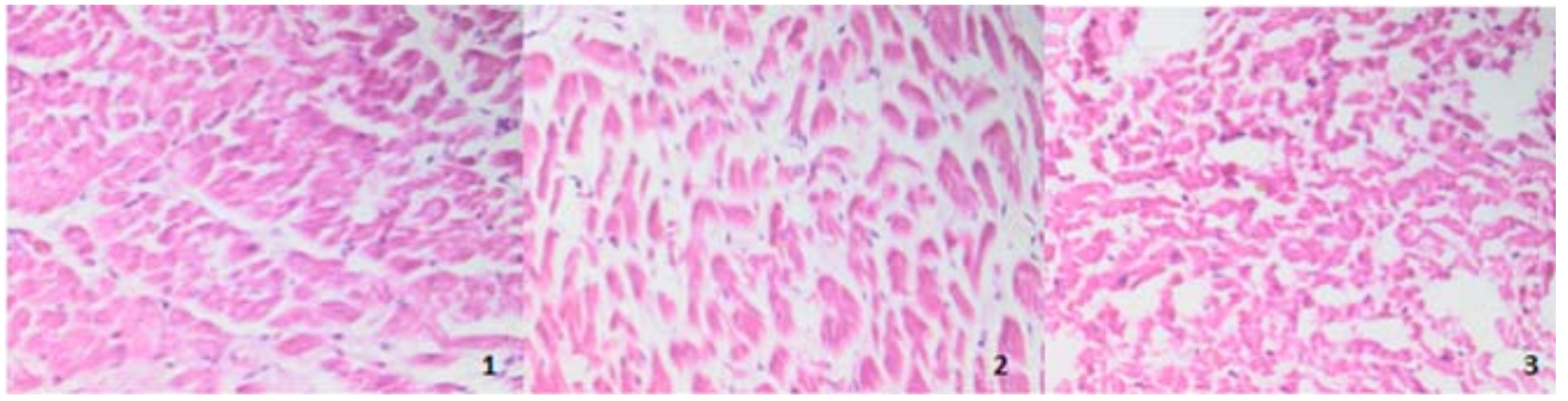

Figure 7. Heart, HE stain, 1-5 days, 40X; 2-8 days 40X; 3-12 days, 40X. 


\section{The Liver}

- 24h: minor autolytic modifications compared to normal histological aspect: cells are slightly swollen with the membrane partially lysed - the cytoplasm extends intrasinusoidal; nuclei are also a little swelled showing early signs of karyolysis.

- 36h: similar aspect to $24 \mathrm{~h}$ one; red blood cells from sinusoidal capillaries are $80 \%$ lysed, the one in portal space vessels being unmodified.

$-48 \mathrm{~h}$ : hepatocytic cytoplasms are more granular; nuclei are either mildly shrunken or ballooned (Figure 8).

$-60 \mathrm{~h}$ : biliary epithelium is almost completely autolyzed - epithelium fragments can still be seen completely detached from basement membrane, or isolated epithelial cubic cells intraluminal.

$-72 \mathrm{~h}$ : microscopically similar to $60 \mathrm{~h}$

-3.5 days: hepatocytes limits are not distinguishable any more.

-4 days: erythrocytes from portal space vessels are almost all autolyzed.

-5 days: in portal vessels red blood cells are completely lysed; leucocytes maintain a fine thin perinuclear cytoplasm (Figure 9).

- 8-22 days: hepatocytes (especially the ones in zone II) show highly retracted and fragmented cytoplasm; the connective texture of the organ can now be easily spotted.

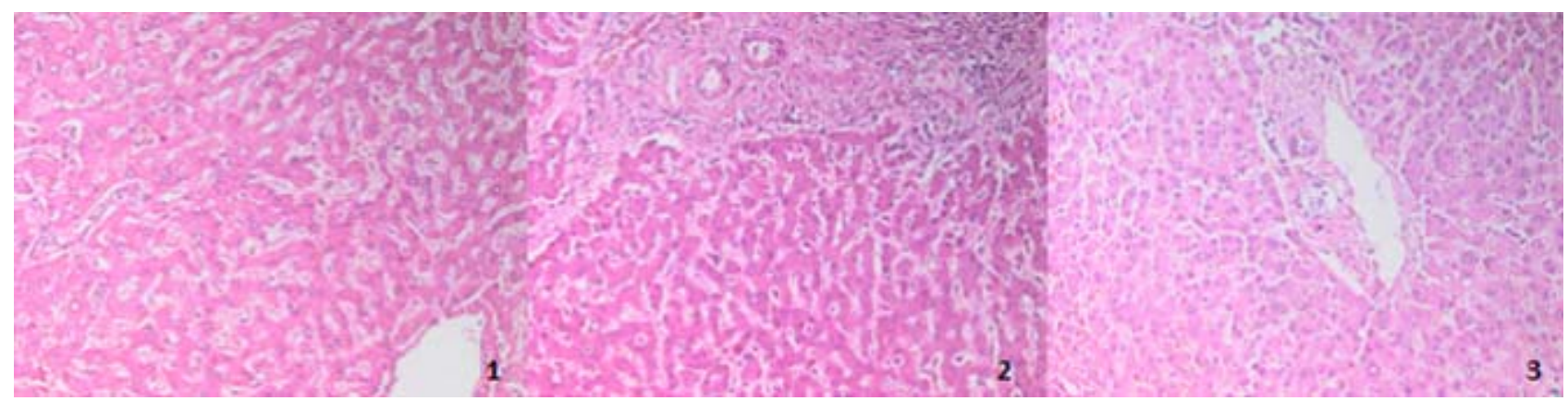

Figure 8. Liver, HE stain, 1-24h, 20X; 2-48h, 20X; 3-60h, $20 \mathrm{X}$.

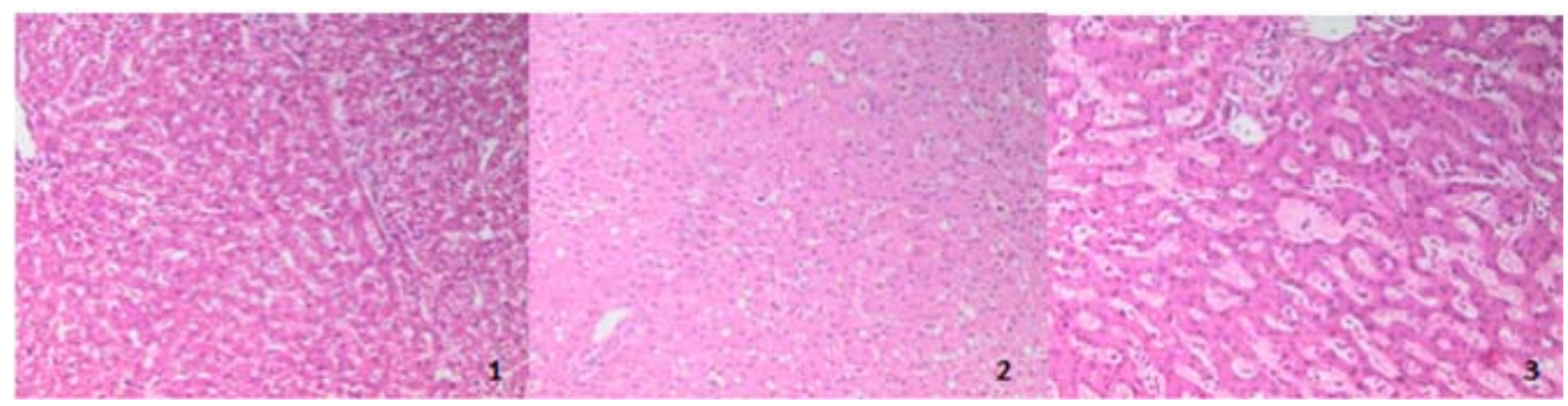

Figure 9. Liver, HE stain, 1-3-5 days, 20X; 2-8 days, 20X; 3-16 days, 20X.

\section{The Pancreas}

$-24 \mathrm{~h}$ : in exocrine pancreas the acinar epithelium is retracted towards the center of the acinus forming cleavage spaces between epithelial cells and the basement membrane; the epithelial secretory cells have intense eosinophilic dusty/fine granular cytoplasm; the cellular membrane is conserved; nuclei are turgescent either showing signs of karyolysis or pyknosis; in endocrine islets cell membranes are almost completely disintegrated, the cytoplasms are fine granular, the nuclei are ballooned or pyknotic with uneven spread chromatin; some adipocytes show cellular membrane and cytoplasm focally fragmented, with cellular contours still well defined and well defined nuclei with homogeneous chromatin (Figure 10).
- 36h: lobular peripheral secretory acini cells are contracted forming cleavage spaces between them and the basement membrane; cytoplasm has a much easily spotted fine granular with little fissures; nuclei have even contour with uniformly dispersed chromatin; in lobular center one can somewhat guess glandular structures - cells have less cytoplasm, intense eosinophilic, well outlined nucleus with chromatin in a thin layer periphery; cells from Langerhans islets are completely autolyzed fragments of filaments and eosinophilic cytoplasm and powder like nuclear debris are visible within the islets defined by the connective skeleton; endothelial cells have unaltered cellular membranes or fine granular cytoplasms, some of them slightly and other completely detached from the basement 
membrane; with the exception of ones from Langerhans islets capillaries, red blood cells are turgescent without signs of membranary lysis.

$-48 \mathrm{~h}$ : in approximately $60 \%$ of pancreatic cells nuclei are not identifiable, with the rest being either karyolysed or pyknotic, with granular cytoplasm slightly fissured; in adipocytes cytoplasm is beginning to fragment and nuclei are not visible;

$-60 \mathrm{~h}$ : highly fragmented cytoplasm diffusely uneven spread in spaces delimited by the conjunctive texture of the gland; in less than $5 \%$ of the cells nuclei can be spotted and inside of larger cytoplasm fragments areas of apparently condensation can be seen (nuclear debris); inside blood vessels erythrocytes can be seen some of them without pigment; tubular epithelium is completely lysed.

$-72 \mathrm{~h}$ : similar aspect with the one at $60 \mathrm{~h}$ (Figure 11).

-3.5-4 days: the fibro-connective structure of gland clearly visible; red blood cells can still be identified; adipocyte cytoplasm has a fine lace appearance. visible.

-5 days: endothelial cells are no longer

-9 days: conjunctive stroma starts to autolyze - it is more pronounced in the center of the acinus (Figure 12).

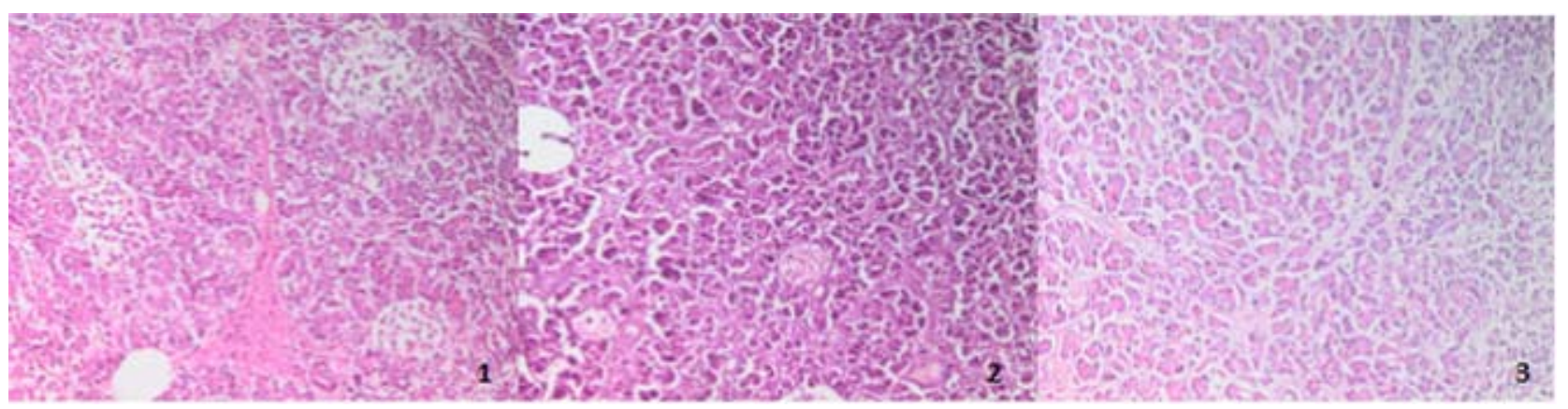

Figure 10. Pancreas, HE stain, 1-24h, 20X; 2-36h, 20X; 3-48h, $20 \mathrm{X}$.

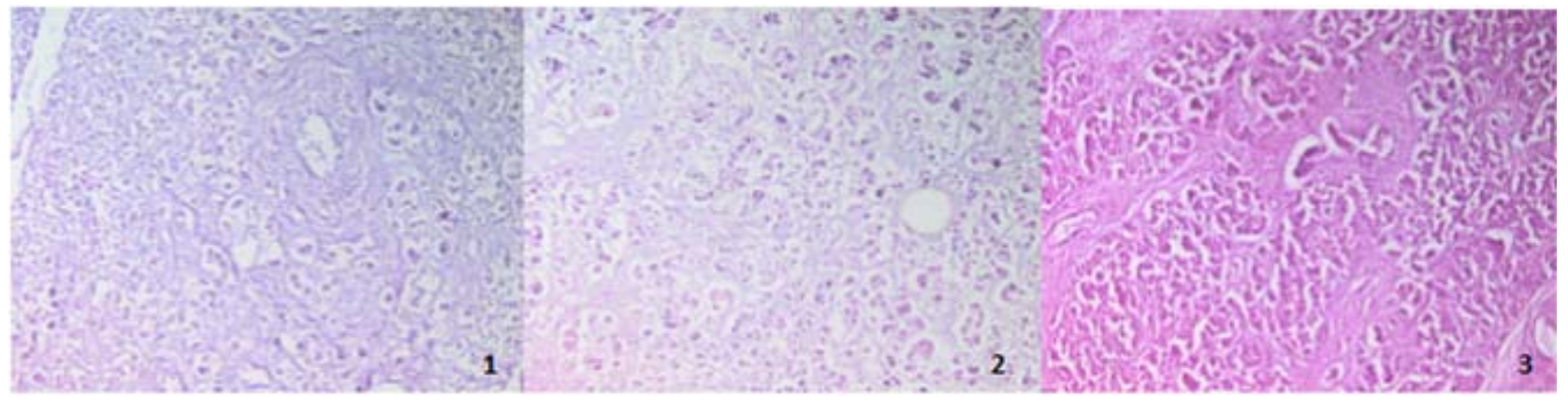

Figure 11. Pancreas, HE stain, 1-60h, 20X; 2-3.5 days, 20X, 3-5 days, 20X.

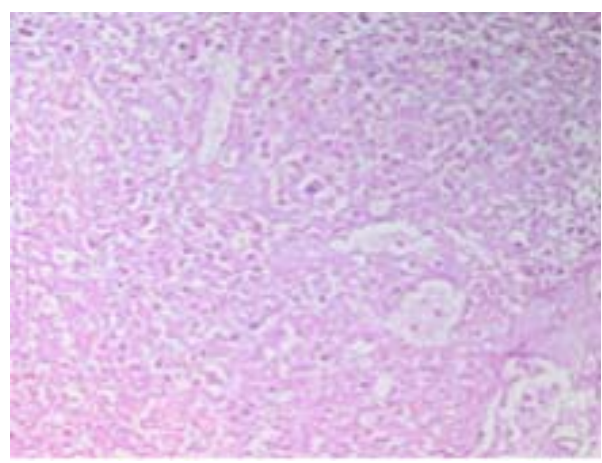

Figure 12. Pancreas, HE stain: 11 days, 20X.

\section{DISCUSSION}

Postmortem body decomposition consists of autolysis and putrefaction processes, the latter often being associated with the term of decomposition [9]. Autolysis represents the destruction of cells and organs by the intracellular enzymes (mostly by the lytic enzymes within lysosomes) [10]; it can 
also be triggered before death and prolonging after. Enzymes being involved in this process [11], from a thermal point of view, autolysis is accelerated by heat, slowed by cold [12] and it can be halted by extreme temperatures below $0^{\circ}$ or over $45^{\circ} \mathrm{C}$ (inactivation or denaturation of the enzymes protein) [13]; the speed at which autolysis occurs is greater in intoxications with biomembrane solvents, high environment humidity, patient's pathology at the time of death (infectious disease, acute pancreatitis, etc.) and decreases if postmortem the body was in dry environment or if it contains large enough quantities of enzymes inhibitors or inactivators (mercury, arsenic and their compounds poisoning).

In 1975 Muller described the order in which organs and tissues undergo the process of autolysis in one organism, autolytic decomposition occurs at different speeds depending on the organ and tissues and structures that compose that organ. The organs and structures with the highest lytic enzyme content are decomposing the easiest - the pancreas autolyzes in a few hours after death, being the organs and the structures rich in collagen much more resistant $[14,15]$ - the digestive mucosa degrades faster than submucosa and the underlying muscular layer of the same digestive segment. Because of the high collagen content the autolytic process occurs at a much lower speed in tendons or aponeuroses.

A particular case of autolysis is represented by dead fetus maceration [16] either in the uterine cavity or extrauterine (fallopian, intraperitoneal) in the case of ectopic pregnancies. In literature cases are mentioned of discovering fetuses at autopsies or years later after the fetus's death as lithopedion.

In case of bodies refrigerated over long periods of time - longer than 8 days - the main differential diagnostic for autolytic modifications is the presence of ischemic necrosis lesions; although the histopathological aspect is similar: eosinophilic fragmented cytoplasm, karyolysis, pyknosis or complete degrading of nuclei, the intra vitam diagnostic of the lesion is made after identifying the inflammatory infiltrate from within the interstitium (more resistant to autolysis).

Different organs have different autolysis rates, decomposition affecting unevenly different regions of the same organ:

- In the lung, autolysis is accelerated by infectious processes; it is also speeded up by air exposure within the alveoli; this is supported by the observation that in lungs with edema (which were not included in the study) pulmonary structures showed only incipient signs of autolytic degradation;
Subepicardial region showed a more advanced state of autolysis compared to the subendocardial myocardium.

- In the liver the first to undergo autolysis are the transition zone hepatocytes.

- In the pancreas centrilobular areas undergo autolysis faster than other regions of the parenchyma.

No matter the organ, the last structures that undergo autolysis or the structures that are altered at a very slow rate are those that contain fibroconnective tissue regardless of their location: intraparenchymal, blood vessels' or tubules' walls.

In the same amount of time, red blood cells autolyze at different intervals of time depending on in which organ or area of the organ they are erythrocytes degrade faster in the sinusoidal capillaries than in portal vessels or in case of the pancreas, the ones within the endocrine isles are lysed well before the ones in the rest of pancreatic parenchyma.

It is difficult to compare autolytic modifications in human organs stored in the relatively controlled environment of a mortuary refrigerator to tissue or organ fragments from animals or human bodies stored in ambient temperature or even in controlled environments at different temperatures, but within a temperature interval that permits enzymes activity. We showed that storage allows temperature heavily slows autolytic processes in comparison with bodies at ambient temperature, where after a couple of hours to a day, putrefaction becomes the dominant destructive process. For future studies on this subject we will address it as follows: on the one hand, to create an animal model of tissue and organ autolysis in cold environments to serve as guidance (this has the advantage of relatively quick results, offering the possibility of minimal variance between subjects and to evaluate autolysis as the body cools down) and, on the other hand, to expand the cadaver database in order to bring the individual variations down to a level that is statistically insignificant.

Acknowledgment: This work is partially supported by the Sectoral Operational Program Human Resources Development (SOP HRD), financed from the European Social Fund and by the Romanian Government under the contract number POSDRU/ $159 / 1.5 / \mathrm{S} / 137390$

The authors are grateful to dr. Eliza Grămadă, dr. Gianina Micu, dr. Răzvan Andrei, dr. Luciana Nichita, dr. Cristiana Popp, dr. Liana Sticlaru, dr. Mirela Ciopea from Pathology Department of "Colentina" Clinical Hospital, Bucharest for performing autopsies and primary diagnosing the cases.

Declaration of interest: The authors of this article declare to have no conflict of interests to disclose. 
Introducere. În medicina legală procesul de autoliză a fost observat şi documentat pentru a determina cât mai exact cu putință intervalul postmortem. Observațiile şi experimentele s-au desfăşurat pe cadavre expuse condițiilor de mediu - căldură, umezeală, curenți de aer, sol şi apă.

Metode. Pentru acest studiu au fost examinate la microscopul optic secțiuni colorate cu hematoxilină şi eozină din probe de organe de la 30 de cadavre autopsiate. S-au urmărit modificările tisulare şi ale structurilor celulare în corelație cu timpul cadavrelor petrecut în camera frigorifică din Morgă până la efectuarea autopsiei, timp care a variat între 24 ore şi 22 zile (528 ore).

Rezultate. Toate organele evaluate (plămân, cord, ficat şi pancreas) au prezentat modficări autolitice severe după 5-8 zile. Cel mai afectat a fost pancreasul, celulele de la nivelul insulelor Langerhans autolizându-se complet la 36 ore. In organe, procesele autolitice se desfăşoară cu viteze diferite în funcție de localizarea la nivelul respectivului organ - profund sau superficial; la nivelul cordului după 4 zile sau mai mult, miocardul subendocardic prezintă un grad mai mic de autoliză decât cel subepicardic.

Concluzie. Procesele autolitice apar mai târziu şi progresează cu viteze diferite într-un mediu controlat rece. Organele prezintă viteze diferite ale autolizei în corelație cu structura şi coținutul lor enzimatic.

Correspondence to: Dr. Vlad Mageriu, MD, Pathology Department of “Colentina” Clinical Hospital, 19-21 Ştefan cel Mare Bvd, Bucharest, Romania, 020125, Phone: 0723149107

E-mail: vladutztg@yahoo.com

\section{REFERENCES}

1. CELATA EN. Postmortem Intervals in Mice Submerged in Aqueous Environments at $20^{\circ} \mathrm{C}$. J Forensic Sci. 2015 Aug 12 . doi: 10.1111/1556-4029.12850.

2. COCKLE DL, BELL LS. Human decomposition and the reliability of a 'Universal' model for post mortem interval estimations. Forensic Sci Int 2015; 253:136.e1-9.

3. MATUSZEWSKI S, KONWERSKI S, FRĄTCZAK K, SZAFAŁOWICZ M. Effect of body mass and clothing on decomposition of pig carcasses. Int J Legal Med. 2014; 128(6):1039-48.

4. DERMENGIU D. Patologie medico-legală. Editura Viața medicală românească, 2002.

5. ZDRAVKOVIĆ M, KOSTOV M, STOJANOVIĆ M. Identification of postmortem autolytic changes on the kidney tissue using PAS stained method. Facta Universitatis, 2006; 13(3):181-184.

6. NERY LR, MOREIRA CR, CESTARI TM, TAGA R, DAMANTE JH. Postmortem acinar autolysis in rat sublingual gland: a morphometric study. J Appl Oral Sci. 2010; 18(5):509-14.

7. LEGEA $104 / 2003$ privind manipularea cadavrelor umane şi prelevarea organelor şi țesuturilor de la cadavre în vederea transplantului republicată 2014. Legea nr. 104/2003 republicată 2014, Monitorul Oficial, Partea I, nr. 213 din 25 martie 2014.

8. HOTĂRÂRE nr. 451 din 1 aprilie 2004 pentru aprobarea Normelor metodologice de aplicare a Legii nr. 104/2003 privind manipularea cadavrelor umane şi prelevarea organelor şi țesuturilor de la cadavre în vederea transplantului, Monitorul Oficial nr., 340/19 apr. 2004.

9. DIMAIO VJ, DIMAIO D. Forensic Pathology, Second Edition, CRC Press LLC, 2001.

10. RUTTY GN. Essentials of autopsy practice current methods and modern trends, Springer-Verlag London Limited, 2006.

11. MAJNO G, JORIS I. Cells, Tissues and Disease: Principles of General Pathology, $2^{\text {nd }}$ Edition, Oxford University Press, 2004.

12. KARADŽIĆ R, ILIĆ G, ANTOVIĆ A, BANOVIĆ LK. Autolytic ultrastructural changes in rat and human hepatocytes. Rom J Leg Med 2010; 18:247 - 52.

13. GUNDLACH G, LUTTERMANN-SEMMER E. The effect of $\mathrm{pH}$ and temperature on the stability and enzymatic activity of prostatic acid phosphatase. Studies on the optimization of a continuous monitored determination of acid phosphatase. J Clin Chem Clin Biochem. 1987; 25(7):441-6.

14. JAY DIX, MICHAEL GRAHAM. Time of death, decomposition and identification: An atlas. CRC Press LLC, 2000.

15. ANA LÍA HENRÍQUEZ HERRERA. Cambios cadavéricos e inmunohistoquímica para estimación de intervalo post mórtemenratas de laboratorio. Universidad de Chile, Santiago, Chile, 2013.

16. SAUKKO P, KNIGHT B, KNIGHT'S Forensic Pathology. Third Edition, Edward Arnold (Publishers) Ltd, 2004.

Received November 23, 2015 